\title{
Implementation of social security chronic disease management program in yogyakarta
}

\author{
Rochana Ruliyandari $^{1 *}$, Bambang Purwanto ${ }^{2}$, AA Subiyanto ${ }^{3}$, Suwarto ${ }^{4}$ \\ ${ }^{1}$ Universitas Ahmad Dahlan, Jl. Kapas No. 9, Semaki, Yogyakarta 55166, Indonesia \\ ${ }^{2,3,4}$ Universitas Sebelas Maret, Jl. Ir. Sutami No. 36, Jebres, Surakarta 57126, Indonesia \\ ${ }^{1}$ ruliyandari27@gmail.com*, ${ }^{2}$ bambangp.solo@yahoo.com, ${ }^{3}$ aasoebijanto@ gmail.com, \\ ${ }^{4}$ suwartosuwarto19111956@gmail.com \\ * corresponding author
}

Submission date: 16 Mei 2021, Receipt date: 8 Juni 2021, Publication date: 1 Juli 2021

\begin{abstract}
Elderly is a global concern since the number of elderly populations is increasing, which also become one of the concerns of the national health insurance (JKN). Health insurance for the elderly has a package of benefits according to physical conditions and degenerative diseases. Since the elderly is susceptible to disease, Indonesia has Healthcare and Social Security Chronic Disease Management Program, National Health Insurance known as Badan Penyelenggara Jaminan Sosial Program Pengelolaan Penyakit Kronis (BPJS Prolanis) to guarantee the health of elderly. This study aims to obtain an overview of the implementation of BPJS Prolanis in the community which located in Yogyakarta in order to give the feedback for this program. This research using qualitative method, with phenomenological research approach, which conducted in Yogyakarta during 2020. The result showed that most of the elderly, which is 221 (77.5\%) elderly already have the health insurance, but only 38.9\% who has BPJS Prolanis. Besides, there are more than 50\% of the elderly have disease that often complained of. Hence, this study proposed suggestions for BPJS Prolanis, such as giving a continues education for the elderly through public health center. Besides, public health center can hold a promotive and preventive activities for the elderly to increase the awareness of the elderly on having the BPJS Prolanis.
\end{abstract}

Keywords: community; elderly; healthcare and social security chronic disease management program; national health insurance

\section{INTRODUCTION}

The population of elderly people in Indonesia has increased sharply by 23.66 million people or $9.03 \%$ of the total population. It is predicted that in 2020 the number of elderly people will increase to $27.08 \%$ million, then 2025 will increase to 33.69 million people (United Nations Population Division, 2017). Increasing in the number of elderly people has triggered one of the mandates of the amendments to the 1945 constitution, namely the development of a social security system for all people and empowering people who are weak and underprivileged according to human dignity. The increase in the number of elderly people has received the attention of the government, among others by enacting Law No. 36 of 2009 concerning Health and Law No. 40 of 2004 concerning the 
National Social Security System (SJSN) which includes healthcare insurance for the elderly which is part of the effort to achieve universal health coverage.

According to World Health Organization (WHO), universal health coverage is a health system where every citizen in the population, including the elderly population, has fair access to promotive, preventive, curative and rehabilitative health services, which are of high quality and are needed by the community at affordable costs. Insurance in universal coverage contains two core elements: 1) Access to fair and quality health services for every citizen; and 2) Protection of financial risks when residents use health services (Murti, 2010). Indonesia is a developing country and one of the countries that is currently in transition to a universal healthcare system. Law No. 40 of 2004 requires every individual in the community to have access to health services to improve their health status. Without insurance protection, most people in Indonesia have to pay out of pocket almost all the costs (full cost) of their health services, both in government hospitals, private hospitals and private doctors' practices.

Most of the population, if do not use insurance, will have the risk of experiencing large medical expenses when sick. In accordance with Law Number 25 of 2016 concerning the national action on elderly health which was carried out between 20162019, namely by providing health services for the elderly and keeping the elderly healthy, independent, and socially and economically productive. This national action hopes to increase the health status of the elderly and increase their life expectancy. As of 2010, data from the Ministry of Health consisted of 352 cities and 33 provinces that had developed Jamkesda program. The public is much more familiar with the development of Jamkesda program than health insurance for the elderly. The number of Jamkesda participants is almost all people in the district, while the BPJS Prolanis participation is expected to increase and the elderly will understand the benefits of the health insurance offered. It is hoped that the elderly has the motivation to increase their independence in maintaining health(Kementerian Kesehatan Republik Indonesia, 2011).

The BPJS Prolanis is a health insurance program for the elderly from government guided by the Healthcare and Social Security (BPJS Kesehatan). This insurance aims to provide health financing guarantees for all the elderly. The specification of this public health insurance program for the elderly is more specifically for those with chronic diseases such as diabetes mellitus, hypertension, and other degenerative diseases. BPJS Prolanis participants also receive maximum service and special handling. The administration of health insurance for the elderly is based on the principles of social insurance and the amount of the premium is determined by the government (Trisnantoro, 2009).

Prolanis itself is a health service system with a proactive approach that is implemented in an integrated manner that involves not only the participants, but also health facilities and BPJS Kesehatan. This is in the context of healthcare for BPJS Kesehatan participants who suffer from chronic diseases to achieve an optimal quality of life with efficient health service costs. The activities written in the Prolanis Practical Guide book consist of: 1) Medical consultation; 2) Prolanis participant education; 3) SMS gateway reminder; 4) Home visit; 5) Club activities (gymnastics); and 6) Monitoring health status (Badan Penyelenggaraan Jaminan Nasional (BPJS), 2010). The goals to be achieved from this Prolanis activity are to encourage participants with chronic diseases to achieve an optimal quality of life. This activity with an indicator that $75 \%$ of registered 
participants who visited the First Level Health Facilities had "good" results on specific examinations for type 2 diabetes mellitus and hypertension according to related clinical guidelines so as to prevent disease complications (Badan Penyelenggaraan Jaminan Nasional (BPJS), 2010).

The Prolanis health financing system is a subsystem of social security, especially targeted at the elderly even though they have other health insurance memberships (such as Axxa Mandiri, Jiwasraya). The principles adopted in the BPJS Prolanis health insurance system have different, more complex and detailed characteristics according to the health conditions of the elderly (Setyawan, 2017). BPJS Prolanis uses a special elderly program-based implementation approach. This program is implemented with techniques that integrate financing and health services for elderly with chronic diseases. This aims to implement an integrated service program for the elderly by increasing the feasibility and efficiency of health services. This program management for the elderly aims to provide comprehensive services for the elderly.

In terms of management, at the end of 2011 Law No. 24 of 2011 concerning the Social Security Administration (UU BPJS) to carry out the constitutional mandate of Law No. 40 of 2004. The implementation of the National Prolanis health insurance is under the authority of the BPJS. The provision of all authority for administering health insurance to BPJS Law which states that BPJS is a legal entity established to administer social security programs. According to Law No. 13 of 1998 concerning the welfare of the elderly so that their life expectancy increases. Elderly is awarded health services. BPJS is tasked with administering the National Social Security System based on the principles of humanity, benefits and social justice for all Indonesian people including the elderly. All forms of National Social Security System administration are held nationally by BPJS. This is reinforced by Kementerian Kesehatan Republik Indonesia (2011) the BPJS Law which states that BPJS Kesehatan organizes health insurance programs for the Indonesian people.

In the implementation of insurance for the elderly, various substantive materials that are needed are not only set out in regulations but must integrate various patterns of elderly health insurance that have been running in the regions. The issue of healthcare benefit packages for the elderly is one of the main issues in the implementation of regional health insurance that must be considered in integrating the national social security system through the BPJS framework (Nasional, n.d.). The transformation of social security in the health sector for the elderly has been taken seriously from year to year. Health financing for the elderly will continue to be increased and allocated by the government. Local government programs for the elderly will continue to be developed as an appreciation for the elderly.

In the implementation of Prolanis, one of the primary health facilities that plays a role in running this program is the public health center (puskesmas). The role of the puskesmas as the spearhead of BPJS Kesehatan tiered services in carrying out Prolanis is very vital (Kementerian Kesehatan Republik Indonesia, 2015). Puskesmas plays an important role in reducing the incidence of non-communicable diseases (PTM), especially for type 2 diabetes mellitus and elderly hypertension (Rahajeng, 2012). The disease is considered capable of being handled in a primary health facility. In addition, the puskesmas also plays an important role in preventing disease complications by carrying out screening or early detection of PTM (Meiriana, Trisnantoro, \& Padmawati, 
2019). According to Samiati and Qomariyah (2019), not all puskesmas' staff got training about Prolanis from BPJS Kesehatan. Besides, there is no general socialization about Prolanis for all the elderly in Klaten District. This study aims to obtain an overview of the implementation of BPJS Prolanis in the community which located in Yogyakarta in order to give the feedback for this program.

\section{RESEARCH METHODS}

This research using qualitative method, with phenomenological approach. A phenomenological approach is carried out with the aim of understanding a social group situation, elderly motivation, interaction, policies and support for the elderly. In this case, an outline of the need for health insurance for the elderly can be obtained. This study seeks to find meaningful relationships accurately by exploring each object and the nature of several individual phenomena in the group. This article focuses on individual motivation in groups, using a quantitative approach using a questionnaire. This emphasizes to explore one of the individual cognitive abilities in the group and social support.

The research was conducted in the Special Region of Yogyakarta in Bantul District, which is in the elderly community in 2020. The data collected included primary data. Primary data were collected through a questionnaire, with a yes and no question to ease the elderly in answering the question. This activity was guided by cadres. There are 285 elderly that become sample for this research. Besides literature study and observation are carried out. Data collection by in-depth interviews, participatory observation, was carried out with the main policy actors from the central level (Head of BPJS), hospital managers, and the community who are directly related to the implementation of BPJS Prolanis in Bantul, Yogyakarta.

\section{RESULTS AND DISCUSSION}

Characteristics of respondents as a sample of elderly research in Bantul Regency, Special Region of Yogyakarta, the characteristics include region, gender, age, education, marital status, income, occupation and religion, According to Handayani (2012) and Sulistyorini (2010), there are several factors that influence the use of public health center for the elderly, including age, gender, education, occupation, knowledge, attitude of health workers, distance from home, family support.

In this study, sociodemographic characteristics were used to determine the condition of the elderly as a sample in Bantul district. Table 1 shows the characteristics of the respondents.

Table 1. Distribution of sociodemographic characteristics of the respondents

\begin{tabular}{llcc}
\hline Characteristic & Description & $\mathbf{n}$ & Percentage (\%) \\
\hline Area & Rural & 129 & 45,3 \\
\cline { 2 - 4 } & Urban & 156 & 54,7 \\
\cline { 2 - 4 } & Total & 285 & 100.0 \\
\hline \multirow{2}{*}{ Gender } & Male & 132 & 46,3 \\
\cline { 2 - 4 } & Female & 153 & 53,7 \\
\cline { 2 - 4 } & Total & 285 & 100.0 \\
\hline
\end{tabular}




\begin{tabular}{llcc}
\hline Characteristic & Description & n & Percentage (\%) \\
\hline Age & $46-55$ years old & 5 & 1,8 \\
\cline { 2 - 4 } & 56-65 years old & 79 & 27,7 \\
\cline { 2 - 4 } & $>65$ years old & 201 & 70,5 \\
\cline { 2 - 4 } & Total & 285 & 100.0 \\
\hline Income & Retired & 23 & 8,1 \\
\cline { 2 - 4 } & Entrepreneur & 32 & 11,2 \\
\cline { 2 - 4 } & Family Support & 147 & 51,6 \\
\cline { 2 - 4 } & Other & 285 & 100.0 \\
\cline { 2 - 4 } & Total & 295 & \\
& & &
\end{tabular}

Sources: Primary Data 2020

More than $50 \%$ of the respondents are live in urban area and female as the gender. The age of the respondents mostly are more than 65 years old. Most of the respondents obtained income from the family support.

Table 2. Distribution of the Number of Elderly Community, Diagnosis Status of Chronic Diseases, Use of "BPJS Prolanis" 2020

\begin{tabular}{llllll}
\hline & & Frequency & Percent & Valid Percent & $\begin{array}{l}\text { Cumulative } \\
\text { Percent }\end{array}$ \\
\hline \multirow{2}{*}{ Valid } & Yes & 111 & 38,9 & 38,9 & 38,9 \\
& No & 174 & 61,1 & 61,1 & 100,0 \\
& Total & 285 & 100,0 & 100,0 & \\
\hline
\end{tabular}

Sources: Primary Data 2020

The data above was taken with 285 elderly respondents, elderly who have chronic disease as much as $38.9 \%$ or 111 respondents. While elderly who do not have chronic disease, there are 174 respondents or $61.1 \%$. The role of the government is needed to be able to provide program information for the elderly so that the elderly can make good use of the program for their health.

In terms of age and physical condition, elderly people really need special attention, especially their health. Hence, family support is needed to maintain their health. One of the supports the family can have is giving the elderly an insurance. Table 2 shows the distribution of rural and urban elderly in having health insurance in 2020.

Table 3. Distribution of Rural and Urban Elderly Participants in individual insurance in 2020

\begin{tabular}{llllll}
\hline & & Frequency & Percent & Valid Percent & $\begin{array}{l}\text { Cumulative } \\
\text { Percent }\end{array}$ \\
\hline \multirow{3}{*}{ Valid } & Yes & 221 & 77,5 & 77,5 & 77,5 \\
& No & 64 & 22,5 & 22,5 & 100,0 \\
& Total & 285 & 100,0 & 100,0 & \\
\hline
\end{tabular}

Sources: Primary Data 2020

As shown in Table 3 there were 221 elderly people who took insurance and 64 people did not participate in insurance at all. There are great benefits when applied in the existing elderly community, especially the programs provided. The qualitative results show that there are various obstacles in providing understanding to the community about the Prolanis BPJS Program, so that the implementation of the program will be more beneficial if applied to individuals in the community because in the community there are cadres who are able to provide information needed by the elderly, limited health human resources and lack of information. will also hinder the uptake of information for participants. 
The needs of the elderly due to their age and physical condition need special attention, the BPJS Prolanis program is very much needed by the elderly, the constraints faced by the limited number of personnel who deal with elderly health problems specifically, such as doctors, nurses and others, are in line with Radina \& Damayanti (2013) states that the incomplete availability of human resources (HR) will affect HR performance in the program process (Radina \& Damayanti, 2013; Saputra, Marlinae, Rahman, \& Rosadi, 2015). Currently, there are still found puskesmas that are difficult to access by the community because they are far from residential areas. Another problem is that the number of medical and non-medical personnel at the puskesmas is limited, the lack of professionals willing to be placed in remote areas, health facilities and infrastructure, economic status, even in some health centers the availability of electricity and clean water is still a problem (Jiang et al., 2018; Kumar \& Shafee, 2014)

This limited workforce is one of the factors that the Prolanis program in remote areas has not benefited maximally by the elderly (Abdullah, Sjattar, \& Kadir, 2017). The lack of programs for the elderly and the lack of information on BPJS Prolanis in remote areas has resulted in the lack of benefit packages received. Elderly people in border areas and small islands when compared to other areas or cities in terms of implementing a concept of health insurance are still deemed lacking (Karim, Moenta, \& Riza, 2018). In the case of the benefit package provided by BPJS Prolanis, it is still not applicable to remote areas. This is due to the limited number of health workers, making it difficult to implement. Many elderly people do not understand the existence of health services for the elderly. Some examples of problems that occur in the implementation of elderly health insurance in remote areas, borders and farthest islands, for example, in Maluku Province (Dinkes Maluku, 2014).

Efforts are also made to improve health services according to standards in Maluku Province by adding basic specialists and other human resources to referral health service facilities. The increase in the number of general practitioners, dentists, midwives and other health workers must be increased in number. Several health centers. From several studies on public health center facilities and infrastructure, there is a need for improvements in facilities and infrastructure for the elderly, for the district of Sleman there are already standard facilities and infrastructure for the public health center (Ruliyandari, 2018).

Health services for the elderly using BPJS Prolanis are expected to be integrated and directed towards universal coverage for the elderly, where all elderly individuals have access to comprehensive health services at affordable costs and maximum services (Chuma \& Okungu, 2011). The design of this system also includes not only the elderly health system, the management system should be designed so that all elderly people have easy access to special health services. This is not in accordance with Permenkes RI No. 43 of 2016 that health services for people with diabetes mellitus and hypertension are provided according to their authority consisting of at least doctors/DLP, nurses, midwives, pharmacists, nutritionists.

From the above, the government gives appreciation to the elderly through the BPJS Prolanis Program, this program is designed to increase the life expectancy of the elderly, the BPJS elderly program is part of Universal health coverage which ensures that health service benefits are distributed based on the need for services not based on the ability to pay (Chuma, Maina, \& Ataguba, 2012). 
The achievement of BPJS Prolanis has been constrained by several things inside and outside the health sector. From an economic perspective, there are always limited resources. The government is obliged to guarantee all health service providers, especially services for the elderly and vulnerable. Vulnerability in the health of the elderly is described as substantial inability, inability to protect oneself from potential harm and vulnerability to harm resulting from the interaction of risk factors and the availability of resources and support from individuals and groups (Allotey, Verghis, Alvarez-Castillo, \& Reidpath, 2012).

Vulnerability and elderly services are discussed in various studies so that the government gives attention through the BPJS Prolanis Program, this program is expected to be able to provide benefits for the elderly, by using elderly patient satisfaction indicators as a benchmark for developing health management to improve services for the elderly. Reform and improvement of elderly health services at various levels requires feedback from external clients through the satisfaction of the health services they receive. Based on a study on the level of patient satisfaction with health insurance in Turkey and the factors that affect consumers using insurance, it shows that most respondents are satisfied with health insurance. High patient satisfaction is associated with increased access to health services and continuity of care (Jadoo, Puteh, Ahmed, \& Jawdat, 2012).

Based on a study of Thailand's experience that has achieved universal health coverage since 2002 through the implementation of a universal coverage scheme for 47 million people out of a total of 65 million people, there is a higher utilization and better financial risk protection for universal health coverage participants who come from the population poor people. BPJS Prolanis is part of a new program launched by Indonesia which is expected to be part of universal health coverage that appreciates the needs of the elderly as an individual program. This BPJS Prolanis is a package of benefits for elderly people with chronic diseases, primary health services, and no co-payment for the services provided (Limwattananon, Tangcharoensathien, Tisayaticom, Boonyapaisarncharoen, \& Prakongsai, 2012).

\section{CONCLUSION}

The role of BPJS Prolanis in society is very much needed seeing the elderly population increasing from year to year. The motivation of BPJS Prolanis participants in rural and urban areas is not different, but it can be seen that the motivation of the participants is higher if this BPJS Prolanis is implemented in the community, participants will feel highly motivated because he has many friends who join the program.

Policy actors at the central level must be able to equalize the perceptions and understanding of policy actors under them in understanding the policy steps to be taken for the elderly. The concept of integrated policy formulation must provide room for greater flexibility and be able to explore the needs of the elderly in health services. The integration of data collection on elderly in a coordinated manner will provide accurate data so that all elderly residents can become BPJS Prolanis participants. It is hoped that elderly people as program beneficiaries and premium payers will receive maximum program benefits. Besides, this study also proposed suggestions for BPJS Prolanis, such as giving a continues education for the elderly through public health center. Moreover, BPJS can giving the public health center staff training so that the public health center can 
hold a promotive and preventive activities for the elderly to increase the awareness of the elderly on having the BPJS Prolanis.

\section{ACKNOWLEDGEMENT}

Thanks to Ahmad Dahlan University for providing research funding assistance and Dr. Muchlas, M.T., as Chancellor. UAD Students: Viga, Lovia, Yoga, and Dwi helped in data collection. Intan and Isti that have helped in data entry and processing. Elderly cadres in Bantul district, Mrs. Novi, Mrs. Umi, Mrs. Gia, Mrs. Mukarni, Mrs. Suprih, Mrs. Kistiah who has helped and facilitate in data collection, also Siti $\mathrm{Ch}$ as a doctor in BPJS Kesehatan Bantul.

\section{REFERENCES}

Abdullah, A., Sjattar, E., \& Kadir, A. (2017). Faktor Penyebab Terjadinya Penurunan Jumlah Kunjungan Peserta Program Pengelolaan Penyakit Kronis (prolanis) di Puskesmas Minasa Upa Kota Makassar. Jurnal Ilmu Kesehatan Diagnosis, 11(4).

Allotey, P., Verghis, S., Alvarez-Castillo, F., \& Reidpath, D. (2012). Vulnerability, Equity and Universal Coverage - A Concept Note. BMC Public Health, 12(1).

Badan Penyelenggaraan Jaminan Nasional (BPJS). (2010). Panduan praktis PROLANIS (Program pengelolaan penyakit kronis). In BPJS Kesehatan. Retrieved from https://bpjs-kesehatan.go.id/

Chuma, J., Maina, T., \& Ataguba, J. (2012). Does the Distribution of Health Care Benefits in Kenya Meet the Principles of Universal Coverage? BMC Public Health, 12(1).

Chuma, J., \& Okungu, V. (2011). Viewing the Kenyan Health System through An Equity Lens: Implications for Universal Coverage. International Journal of Equity Health, 10(1).

Dinkes Maluku. (2014). Profil Kesehatan Provinsi Maluku Tahun 2014. In Journal of Chemical Information and Modeling (Vol. 53). Retrieved from http://www.depkes.go.id/resources/download/profil/PROFIL_KES_PROVINSI_20 12/17_Profil_Kes.Prov.Bali_2012.pdf

Jadoo, A., Puteh, W., Ahmed, Z., \& Jawdat, A. (2012). Level of Patients' Satisfaction toward National Health Insurance in Istanbul City-Turkey. BMC Public Health, 12.

Jiang, M., Yang, G., Fang, L., Wan, J., Yang, Y., \& Wang, Y. (2018). Factors Associated with Healthcare Utilization among Community-Dwelling Elderly in Shanghai, China. PloS One, 13(12), 1-22.

Karim, M., Moenta, A., \& Riza, M. (2018). Implementasi Kebijakan Pemerintah Daerah di Bidang Kesehatan Masyarakat Melalui Jaminan Kesehatan Nasional. Amanna Gappa, 26(1).

Kementerian Kesehatan Republik Indonesia. (2011). Pedoman Pelaksana Jaminan Kesehatan Masyarakat. 
Kementerian Kesehatan Republik Indonesia. (2015). Profil Kesehatan Indonesia Tahun 2014. Jakarta.

Kesehatan Kementerian. Peraturan Menteri Kesehatan Republik Indonesia Nomor 43 Tahun 2016 Tentang Standar Pelayanan Minimal Bidang Kesehatan. , (2016).

Kumar, R., \& Shafee, M. (2014). Assessment of Morbidity Pattern and Its Correlates among Elderly Population In Rural Area of Perambalur, Tamilnadu, India. International Journal of Biomed Research, 5(4).

Limwattananon, S., Tangcharoensathien, V., Tisayaticom, K., Boonyapaisarncharoen, T., \& Prakongsai, P. (2012). Why Has the Universal Coverage Scheme in Thailand Achieved A Pro-Poor Public Subsidy for Health Care? BMC Public Health, 12.

Meiriana, A., Trisnantoro, L., \& Padmawati, R. (2019). Implementasi Program Pengelolaan Penyakit Kronis (PROLANIS) pada Penyakit Hipertensi di Puskesmas Jetis Kota Yogyakarta. Jurnal Kebijakan Kesehatan Indonesia, 8(2), 51.

Murti, B. (2010). Strategi Untuk Mencapai Universal Pelayanan Kesehatan di Indonesia. Universitas Sebelas Maret.

Nasional, D. J. S. (n.d.). Peta Jalan Menuju Jaminan Kesehatan Nasional 2012-2019.

Radina, D., \& Damayanti, N. (2013). Evaluasi Pelaksanaan Standar Pelayanan Minimal pada Program Penemuan Penderita Pneumonia Balita. Jurnal Administrasi Kesehatan Indonesia, 1(4).

Rahajeng, E. (2012). Upaya Pengendalian PTM di Indonesia. Buletin Jendela Data Dan Informasi Kesehatan.

Ruliyandari, R. (2018). Implementasi Program "Santun Lansia" Puskesmas Kabupaten Sleman. Jurnal Fakultas Kesehatan Masyarakat, 12(1), 8-14.

Samiati, \& Qomariah, N. (2019). Evaluasi Program Pengelolaan Penyakit Kronis (Prolanis) di Puskesmas Prambanan Kabupaten Klaten.

Saputra, M., Marlinae, L., Rahman, F., \& Rosadi, D. (2015). Program Jaminan Kesehatan Nasional dari Aspek Sumber Daya Manusia Pelaksana Pelayanan Kesehatan. Jurnal Kesehatan Masyarakat, 11(1), 32-42.

Setyawan, F. (2017). Sistem Pembiayaan Kesehatan. Saintika Medika, 11(2), 119.

Trisnantoro, L. (2009). Apakah Undang-Undang Sistem Jaminan Sosial Nasional Dapat Terus Dilaksanakan? Sebuah Analisis Sejarah dan Budaya. Jurnal Manajemen Pelayanan Kesehatan, 12(03), 113.

United Nations Population Division. (2017). World Population Prospects. New York.

Undang-Undang No. 13 Tahun 1998 tentang Kesejahteraan Lanjut Usia. (1998). 
Undang-Undang No. 24 Tahun 2011 tentang Badan Penyelenggara Jaminan Sosial. (2011).

Undang-Undang No. 25 Tahun 2016 tentang Aksi Nasional Kesehatan Lanjut Usia. (2016).

Undang-Undang No. 40 Tahun 2004 tentang Sistem Jaminan Sosial Nasional. (2004).

Undang-Undang No. 36 Tahun 2009 tentang Kesehatan. (2009). 